\section{POMPA AIR TENAGA SURYA UNTUK IRIGASI PER- SAWAHAN BAGI MASYARAKAT DESA KARANG REJO, PESAWARAN, LAMPUNG}

Herman Halomoan Sinaga, Diah Permata, Noer Soedjarwanto, Nining Purwasih

Teknik Elektro, Universitas Lampung

$\begin{array}{lrl}\text { Article history } & \\ \text { Received } & \text { : } & 07-10-2020 \\ \text { Revised } & : & 17-01-2021 \\ \text { Accepted } & : & 17-02-2021\end{array}$

\section{*Corresponding author}

Herman Halomoan Sinaga Email:

herman.h.sinaga@eng.unila.ac.id

\begin{abstract}
Abstrak
Salah satu sumber energi terbarukan yang banyak tersedia di Indonesia adalah energi matahari. Energi matahari dapat dikonversikan menjadi energi listrik melalui konversi langsung sel-surya. Metode konversi energi matahari menjadi energi listrik disebut dengan sistem pembangkit listrik tenaga surya (matahari). Energi yang dihasilkan pembangkit listrik tenaga surya dapat dipergunakan untuk menggerakkan pompa air. Kegiatan pengabdian pada masyarakat ini bertujuan untuk memberikan edukasi dan implementasi pemasangan pompa air irigasi bagi masyarakat Desa Karang Rejo Kecamatan Negeri Katon Kabupaten Pesawaran Provinsi Lampung. Pemilihan didasarkan atas terjadinya kekeringan yang mengakibatkan gagal panen padi masyarakat Desa Karang Rejo pada tahun 2019 yang diakibatkan curah hujan yang sangat rendah. Sistem Pompa air tenaga surya yang dikembangkan menggunakan panel sel surya berkapasitas 200 WP. Baterai dengan kapasitas total $90 \mathrm{AH}$ dipergunakan untuk menyimpan energi listrik yang dihasilkan dan dipergunakan untuk menyuplai daya ke pompa air DC berdaya 60 Watt. Hasil pengujian memperlihatkan pompa mampu menyuplai air sebesar 29 liter per menit dengan head 4 meter.
\end{abstract}

Kata Kunci: Irigasi; Kekeringan Lahan Pertanian; Pompa Air; Sel Surya

\begin{abstract}
One of the renewable energy sources which abundant in Indonesia is solar energy. Solar energy can be converted to become electrical energy by using a solar cell. This method is known as solar electric power generation. The electric power production by the solar power generation can be used to operate a water pump. This community service activity aims to provide education and implementation of irrigation water pumps for Karang Rejo village society, Negeri Katon residents, Pesawaran District, Lampung Province. Karang Rejo village's main reason as this works' location is due to dry out the season in 2019. The dry season caused the crop to fail as the water supply is too low. Water pump solar cell-powered implemented in this work uses solar cell panels with a total capacity of 200 WP. A battery with a total capacity of $90 \mathrm{AH}$ is used to store the electric power and connect to supply power to a 60 watts DC power pump. The testing results show the pump can supply water up to 29 liters per minute with a head up to 4 meters.
\end{abstract}

Keywords: Irrigation; Farm Dry Out; Water Pump; Solar Cell

\section{PENDAHULUAN}

Kebutuhan air irigasi bagi petani merupakan hal yang sangat krusial. Volume air tertentu dibutuhkan petani untuk memenuhi kebutuhan evaporasi pertanian. Kebutuhan evaporasi ini untuk menggantikan kehilangan air akibat adanya proses penguapan pada permukaan tanah pertanian maupun akibat air permukaan yang dipergunakan oleh tanaman pertanian (Sosrodarsono \& Takeda, 1978) sehingga kebutuhan air merupakan komponen yang sangat vital bagi pertanian.

Petani di Desa Karang Rejo sangat mengandalkan pengairan tadah hujan (Badan Pusat
Statistik Pesawaran, 2017) karena kontur geografis desa yang sangat variatif. Berdasarkan data sawah di Desa Karang Rejo terdapat 29,50 Ha sawah dengan irigasi teknis dan 15,00 Ha sawah tadah hujan (Badan Pusat Statistik Pesawaran, 2017). Sistem persawahan tadah hujan mengandalkan air yang tersedia secara alami. Pada saat musim kemarau, persawahan tadah dapat mengalami kekurangan air. Pada tahun 2019, akibat curah hujan yang sangat rendah ratusan sawah di desa Karang Rejo mengalami gagal panen. Irigasi persawahan mengalami kekeringan dan petani harus mengandalkan pompa mengairi persawahannya. Biaya 
pengoperasian pompa sangat tinggi mencapai Rp 50.000 per jam. Hal ini dirasakan sangat memberatkan petani sehingga banyak petani membiarkan padinya gagal panen (Kupastuntas, 2019).

Salah satu upaya yang telah dilakukan pemerintah Kabupaten pesawaran untuk mengatasi kekurangan air persawahan disaat musim kemarau adalah dengan menyediakan pompa (Kupastuntas, 2019) yang berfungsi memompa air dari sungai atau air tanah ke persawahan. Pompa air berbahan bakar diesel merupakan sistem pengairan dikala musim kemarau yang paling banyak dipergunakan (Pusat Data dan Informasi Energi dan Sumber Daya Mineral KESDM, 2010), yakni mencapai 44\% pompa air. Penggunaan pompa diesel ini tentu berdampak sangat luas seperti polusi udara yang dihasilkan gas buang pompa diesel yang dipergunakan. Hal lain yang juga menjadi pertimbangan utama adalah biaya yang tidak sedikit yang harus dikeluarkan oleh petani untuk menyediakan mesin diesel dan biaya bahan bakarnya karena luas dan tersebarnya area persawahan yang ada.

Salah satu upaya yang dapat dilakukan untuk membantu petani dalam pengairan pertaniannya adalah pemanfaatan teknologi ramah lingkungan dan terbarukan yang berbiaya murah. Pengairan bertenaga surya merupakan salah satu alternatif pompa air pertanian yang dapat dikembangkan (Sanjaya et al., 2019). Irigasi pertanian yang memanfaatkan tenaga surya memiliki beberapa keunggulan dibanding dengan irigasi pengairan konvensional, seperti efisiensi penggunaan air yang tinggi, mencegah erosi dan perkembangan gulma yang sedikit (Cuadros et al., 2004), menurunkan tekanan kelembaban tanah (Pande et al., 2003), biaya operasi lebih rendah bahkan dapat diabaikan, dan penyediaan energi melibatkan masyarakat lokal (Ghoneim, 2006; Vinayak \& Wandre, 2015).

Pompa air tenaga surya dapat dipergunakan untuk mengairi sistem pertanian (Apribowo et al., 2019; Sanjaya et al., 2019; Zainuddin \& Darmawan, 2017), dengan kapasitas debit air yang bervariasi, tergantung pada kebutuhan. Sanjaya et al. (2019) mendesain sistem pompa air tenaga surya yang mampu mengairi areal persawahan dengan luas sampai 55 hektar. Sistem pompa air yang didesain menggunakan solar panel seluas $300 \mathrm{~m}^{2}$ yang akan menghasilkan energi listrik mencapai lebih dari 52 $\mathrm{kW}$. Untuk sistem pengairan yang lebih kecil, Apribowo et al. (2019), mengembangkan pompa air berskala kecil dengan daya 120 watt yang dipergunakan untuk memompa air dengan debit mencapai 15 meter kubik per hari. Sistem pompa air dengan daya kecil ini memiliki keunggulan yakni bersifat mobil. Untuk daya yang lebih rendah, Setiadi et al. (2017), mengembangkan pompa air dengan daya yang hampir sama yakni sekitar 150 watt, dan debit air yang dihasilkan mencapai 42 liter per detik atau sekitar 2.5 meter kubik per jam.

Kegiatan pengabdian ini menawarkan solusi untuk mengatasi kekurangan air pada persawahan tadah hujan di desa Karang Rejo, Kabupaten Pesawaran dengan mendesain dan membuat pompa air tenaga surya yang dapat dipindahkan. Sistem tersebut mudah dipindahkan dan mudah dioperasikan. Sistem dibuat dengan dimensi yang kecil dan kompak. Sistem yang kompak didapat dengan menempatkan seluruh sistem dalam satu kesatuan sehingga memudahkan untuk memindahkan pompa air tersebut. Sistem dibuat untuk memudahkan pengoperasian dengan menggunakan komponen-komponen yang dapat dirakit oleh masyarakat pengguna. Pompa yang dipergunakan menggunakan tegangan 12 Volt DC untuk menghindari bahaya sengatan listrik.

\section{METODE PELAKSANAAN}

Kegiatan PKM ini terbagi atas dua bagian pelaksanaan, yakni desain dan pembuatan pompa air tenaga surya dan sosialisasi dan penggunaan pompa air tenaga surya di lapangan (Desa Karang Rejo, Lampung).

\section{Desain Pompa Air Tenaga Surya}

Sumber energi penggerak pompa air yang didesain menggunakan tenaga sel surya. Skema desain utama sistem pompa air tenaga surya didesain sesederhana mungkin dan aman bagi masyarakat pengguna (Gambar 1). Untuk mendapatkan desain yang sederhana, komponen sumber energinya hanya menggunakan 3 komponen utama, yakni: panel sel surya, baterai dan kontroller. Salah satu faktor lain dalam desain, yakni keamanan, dilakukan dengan menggunakan sistem tegangan 12 volt. Tegangan 12 volt relatif aman karena tidak menimbulkan bahaya tersengat listrik. Sistem pompa dengan tegangan DC juga menghasilkan efisiensi yang sangat tinggi (Dursun \& Saygin, 2005; Lawrance et al., 1995).

Pompa yang dipergunakan dalam kegiatan pengabdian ini memiliki kapasitas daya $60 \times 2=120$ watt, dengan kapasitas penyaluran air teoritis sebesar 63 liter per menit. Panel sel surya dipilin tipe monocrystalline, karena memiliki efisiensi yang lebih baik dibandingkan dengan tipe polycrystalline (Nogueira et al., 2015) dengan tingkat efisiensi mencapai 14,5 \% (Patel, 1999). Untuk menyalurkan energi listrik yang ditangkap oleh sel surya dipergunakan sebuah kontroller 30 Ampere. Kontroller juga berfungsi untuk mengisi baterai sebagai sumber daya listrik jika sinar matahari tidak tersedia. 


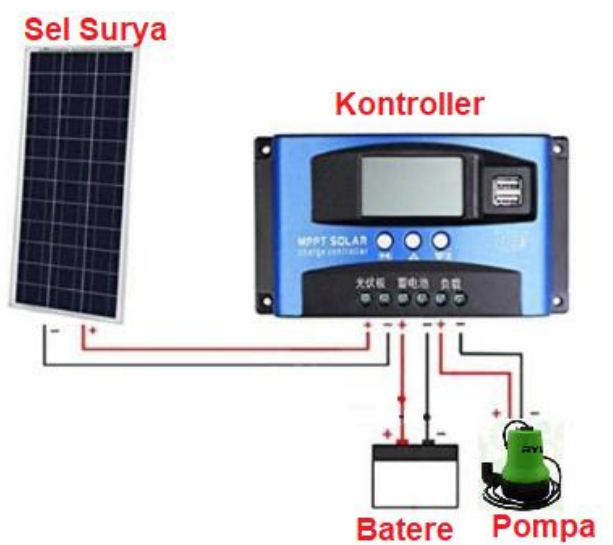

Gambar 1. Diagram desain sistem pompa air tenaga surya

Semua komponen sumber energi (pembangkit listrik tenaga surya) ditempatkan pada meja/dudukan yang bersifat mobil (Gambar 2). Dua buah panel sel surya ditempatkan di atas meja. Penempatan panel sel surya di atas meja selain untuk menangkap energi surya, juga berfungsi sebagai pelindung komponen kontroller dan baterai yang ditempatkan tepat di bawah panel. Kontroller dan baterai ditempatkan dalam kotak besi di bawah panel sel surya.

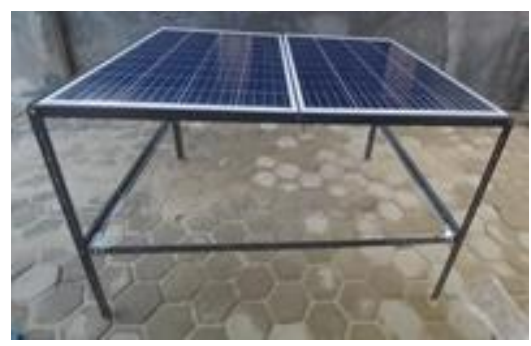

Gambar 2. Meja dudukan sistem pompa air tenaga surya, sel surya terpasang.

Pompa air dihubungkan ke kontroller melalui kabel sepanjang 25 meter. Sehingga pompa dapat leluasa di pindah-pindah tanpa menggeser meja panel sel surya. Sebuah selang berdiameter 1,5 inci dihubungkan ke pompa untuk menyalurkan air yang telah dipompa. Panjang selang sebesar 25 meter, sehingga mudah untuk menjangkau pertapakan sawah yang akan diairi.

\section{Sosialisasi dan Penggunaan Pompa Air Tenaga Surya}

Sosialisasi dilakukan dengan mempresentasikan pompa air tenaga surya kepada masyarakat desa Negeri Katon, Lampung. Presentasi dilakukan untuk menjelaskan tema dan maksud kegiatan yang dilakukan. Penjelasan mengenai prinsip dasar pompa air tenaga surya diberikan dengan menampilkan slide penjelasan prinsip dan perakitan sistem pompa. Secara garis besar kegiatan sosialisasi dibagi 3 yakni:

a. Pengelolaan pengairan menggunakan pompa air tenaga surya di persawahan

b. Metode penggunaan sistem pompa air tenaga surya sebagai sistem pengairan di kala terjadi kekurangan air

c. Penanganan teknis, maintenance dan perbaikan ringan pada sistem pompa air tenaga surya.

Sosialisasi yang dilakukan di rumah salah seorang penduduk (Gambar 3). Setelah sosialisasi selesai dilakukan, kegiatan dilanjutkan dengan demo perakitan dan uji coba pompa air tenaga surya. Diskusi dilakukan dengan menunjukkan secara langsung cara kerja sistem pompa air tenaga surya. Kegiatan ini juga membahas maintenance yang diperlukan sistem supaya dapat bekerja optimal (Gambar 4).

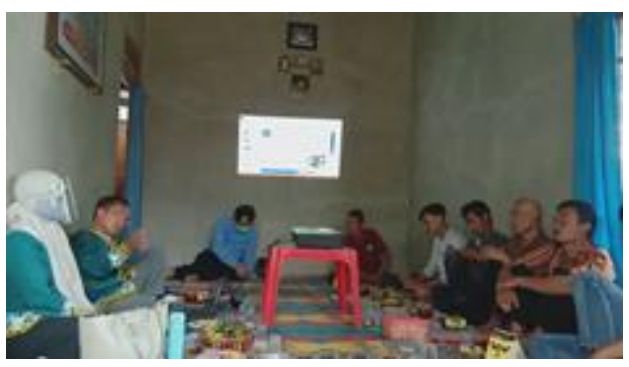

Gambar 3. Sosialisasi kegitan di rumah salah seorang penduduk

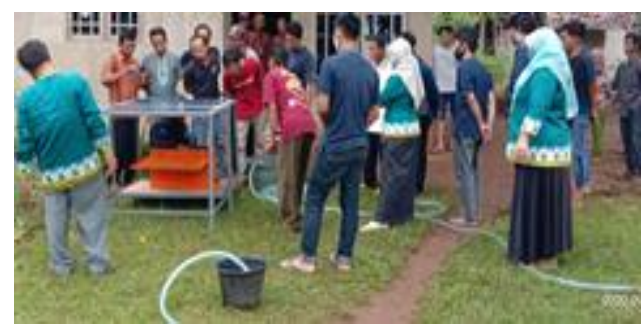

Gambar 4. Kegiatan perakitan pompa air tenaga surya dan diskusi prinsip kerja dan maintenance sistem pompa air tenaga surya.

\section{PEMBAHASAN}

\section{Pembuatan Mobil Pompa Tenaga Surya}

Pompa tenaga surya yang direncanakan menggunakan tegangan $12 \mathrm{~V}$ DC. Beban pompa submersible memiliki kapasitas daya sebesar 60 watt x 2 = 120 Watt. Besar energi yang dibutuhkan dapat dihitung dengan menggunakan persamaan 1 dengan $W=$ Energi (Watt jam), $P=$ daya pompa (Watt), dan $t=$ waktu (jam)

$W=P \times t$ 
Jika diasumsikan pompa akan menyala selama 6 jam per hari, maka besar energi yang dibutuhkan per harinya adalah $W=120$ Watt $\times 6$ jam $=720$ Watt jam (Wh) Jika diasumsikan sinar matahari di pesawaran akan tersedia selama 6 jam perhari (Badan Pusat Statistik Pesawaran, 2017), maka daya Watt puncak perhari dengan persamaan 2 dengan $W=$ daya yang dibutuhkan dan $\Delta t=$ rerata matahari bersinar per hari

$W_{p}=\dot{W} \times \Delta t$

Jadi besar daya Watt puncak adalah $W_{p}=720$ Watt jam / 6 jam = 120 Watt puncak. Jika dipergunakan solar panel berdaya 100 WP, maka jumlah solar panel yang dibutuhkan adalah 120/100 = 1,2 panel. Dengan pendekatan maka dipergunakan solar panel sebanyak 2 buah.

Jika dimisalkan sinar matahari tidak tersedia, maka sumber energi direncanakan menggunakan baterai dan pompa beroperasi selama 6 jam, maka besar daya yang dibutuhkan pompa untuk bekerja selama 6 jam adalah 720 Watt Jam. Baterai yang dipergunakan memiliki voltase 12 Volt, maka besar arus yang dibutuhkan selama satu jamnya adalah: 720/12 = 60 Ampere Jam.

Dengan memperhitungkan kemungkinan drop tegangan saat baterai sudah lemah, maka besar kapasitas baterai diperbesar menjadi 90 Ampere Jam. Baterai berkapasitas 90 Ampere Jam dapat menggunakan baterai tunggal atau 2 buah baterai berkapasitas 45 Ampere Jam yang dipasang paralel. Dalam kegiatan pengabdian ini dipilih 2 buah baterai berkapasitas 45 Ampere Jam dengan alasan dimensi yang lebih kecil dibandingkan dengan sebuah baterai 90 Ampere Jam. Pemilihan ini dapat mempermudah instalasi peralatannya di lapangan. Penggunaan dua buah baterai juga akan memberi tingkat keandalan yang lebih baik. Data teknis rancangan pompa tenaga surya yang dibuat ditunjukkan pada Tabel 1.

Tabel 1. Spesifikasi teknis pompa tenaga surya yang dibuat

\begin{tabular}{clc}
\hline No & \multicolumn{1}{c}{ Spesifikasi } & Jumlah \\
\hline 1 & Daya total panel sel Surya (Watt) & 200 \\
2 & Daya pompa air (Watt) & 60 \\
3 & Lama penggunaan per hari (jam) & 6 \\
4 & Kapasitas Baterai (Ampere Jam) & 90 \\
5 & Debit Air per menit (liter/menit) & 29 \\
6 & Debit Air per hari (m³/hari) & 10,4 \\
\hline
\end{tabular}

\section{Kemampuan Memompa Air}

Diagram konstruksi peralatan pompa air yang dibuat ditunjukkan pada Gambar 1. Pompa yang dipergunakan merupakan tipe submersible dan dihubungkan ke output controller melalui kabel listrik sepanjang 25 meter. Sebuah selang sepanjang 25 meter dihubungkan ke pompa untuk mengalirkan air ke area persawahan atau lokasi pertanian yang membutuhkan.

Pengujian kemampuan sistem dilakukan dengan mengisi baterai menjadi penuh dengan menempatkan solar panel di bawah matahari. Pengisian baterai dikendalikan oleh kontroller dan pengisian baterai dapat langsung dilihat pada panel controller. Pengujian kapasitas pompa dilakukan dengan menempatkan pompa pada sumber air dan air output pompa ditampung pada wadah 100 liter. Hasil pengujian (Tabel 1) menunjukkan bahwa sistem dapat memompa air dengan kecepatan rerata 29 liter per menit. Setiadi et al. (2017), menghasilkan pompa air tenaga surya yang mencapai 44 liter per menit, namun menggunakan panel sel surya mencapai 6 buah, dibandingkan jumlah sel surya yang dipergunakan dalam kegiatan ini hanya 2 buah. Hasil ini memperlihatkan bahwa sistem pompa air tenaga surya yang dibuat sudah memiliki kemampuan yang baik. Dengan debit sebesar ini, maka jika diasumsikan pompa dinyalakan 6 jam per hari, debit air yang dapat dipompa mencapai 10,4 meter kubik per hari.

\section{KESIMPULAN}

Kegiatan pengabdian pada masyarakat desa Karang Rejo, Pesawaran, Lampung dilaksanakan oleh tenaga dosen dan mahasiswa Jurusan Teknik Elektro Universitas Lampung. Pada kegiatan pengabdian yang dilaksanakan di perkenalkan sistem pompa air tenaga surya yang mampu memompa air dengan debit 29 liter per menit. Jika pompa dinyalakan selama 6 jam, maka pompa akan mampu memompa air sebanyak 10,4 meter kubik. Keberlanjutan program PKM ini kedepannya adalah mengembangkan sistem pengairan dengan debit dan durasi pengairan yang dikendalikan secara otomatis.

\section{UCAPAN TERIMA KASIH}

Penulis mengucapkan terimakasih kepada LPPM UNILA yang telah mendanai kegiatan Pengabdian pada Masyarakat ini dengan kontrak no. 1606/UN26.21/PM/2020.

\section{DAFTAR PUSTAKA}

Apribowo, C. H. B., Arifin, Z., \& Adriyanto, F. (2019). Mobile Pompa Air Tenaga Surya Untuk Irigasi Pertanian. Jurnal Puruhita, 1(1), 6-11. https://journal.unnes.ac.id/sju/index.php/puruhita/ar ticle/view/28319

Badan Pusat Statistik Pesawaran. (2017). Statistik Kesejahteraan Rakyat Kabupaten Pesawaran Tahun 2017. 
https://pesawarankab.bps.go.id/publication/2017/1 2/29/0128f45e7985507ddc19clef/statistikkesejahteraan-rakyat-kabupaten-pesawaran-tahun2017.html

Cuadros, F., López-Rodrı $\square$ guez, F., Marcos, A., \& Coello, J. (2004). A procedure to size solar-powered irrigation (photoirrigation) schemes. Solar Energy, 76(4), 465473.

https://doi.org/https://doi.org/10.1016/j.solener.2003. 08.040

Dursun, M., \& Saygin, Ali. (2005). System Analysis of switched reluctance motor driver with boost converter for a photovoltaic array irrigation system. 3rd Renewable Energy Sources Symposium, 57-62. https://avesis.gazi.edu.tr/publication/details/c9d8fd 4a-50ac-40ac-a6fc-88clec30ca8c/emsystem-ememanalysis-em-emof-em-emswitched-ememreluctance-em-emmotor-em-emdriver-ememwith-em-emboost-em-emconverter-em-emforem-ema-em-emphotovoltaic-em-emarray-ememirrigation-em-emsystem

Ghoneim, A. A. (2006). Design optimization of photovoltaic powered water pumping systems. Energy Conversion and Management, 47(11), 1449-1463. https://doi.org/https://doi.org/10.1016/j.enconman.2 005.08 .015

Kupastuntas (2019). Ratusan Hektare Sawah di Pesawaran Terancam Kekeringan, Dinas Pertanian Janji Carikan Solusi.

https://www.kupastuntas.co/2019/07/31/ratusanhektare-sawah-di-pesawaran-terancam-kekeringandinas-pertanian-janji-carikan-solusi/

Lawrance, W., Wichert, B., \& Langridge, D. (1995). Simulation and performance of a photovoltaic pumping system. Proceedings of 1995 International Conference on Power Electronics and Drive Systems. PEDS 95, 513518. https://doi.org/10.1109/PEDS.1995.404869

Nogueira, C. E. C., Bedin, J., Niedzialkoski, R. K., De Souza, S. N. M., \& Das Neves, J. C. M. (2015). Performance of monocrystalline and polycrystalline solar panels in a water pumping system in Brazil. Renewable and Sustainable Energy Reviews, 51, 1610-1616. https://doi.org/https://doi.org/10.1016/j.rser.2015.07.0 82

Pande, P. C., Singh, A. K., Ansari, S., Vyas, S. K., \& Dave, B. K. (2003). Design development and testing of a solar PV pump based drip system for orchards. Renewable Energy, 28(3), 385-396. https://doi.org/https://doi.org/10.1016/\$0960$1481(02) 00037-X$

Patel, M. R. (1999). Wind and Solar Power Systems. Taylor \& Francis. https://books.google.co.id/books?id=†NPElves7SUC

Pusat Data dan Informasi Energi dan Sumber Daya Minera KESDM. (2010). Indonesia Energi Outlook (IEO). https://www.esdm.go.id/assets/media/content/cont ent-indonesia-energy-outlook-2010-484r lpu.pdf

Sanjaya, O. I., Giriantari, I. A. D., \& Kumara, I. N. S. (2019). Perancangan Sistem Pompa Irigasi Pembangkit Listrik Tenaga Surya (PLTS) Untuk Pertanian Subak Semaagung. Jurnal Spektrum, 6(3), 114-121. https://ojs.unud.ac.id/index.php/spektrum/article/vi ew/52824

Setiadi, R. L., Suryadi, E., \& Dwiratna, S. (2017). Kajian Pemanfaatan Pompa Air Tenaga Surya untuk Kebutuhan Irigasi di Lahan Pertanian. Prosiding Seminar Nasional Lahan Suboptimal 2017, 649-659. https://docplayer.info/92973894-Kajianpemanfaatan-pompa-air-tenaga-surya-untukkebutuhan-irigasi-di-lahan-pertanian.html

Sosrodarsono, S., \& Takeda, K. (1978). Hidrologi untuk pengairan. Jakarta: PT. Pradnya Paramita https://books.google.co.id/books?id=89GBAQAACA AJ

Vinayak, S., \& Wandre, S. (2015). Solar photovoltaic water pumping system for irrigation: A review. African Journal of Agricultural Research, 10(22), 2267-2273. https://doi.org/10.5897/AJAR2015.9879

Zainuddin, M., \& Darmawan, M. (2017). Pemanfaatan Pompa Air Tenaga Surya (PATS) Untuk Irigasi Lahan Sawah Di Kelurahan Tanggikiki Kota Gorontalo. Ngayah: Majalah Aplikasi IPTEKS, 8(2), 151-158. https://jurnal.unmas.ac.id/index.php/ngayah/article /view/879 